\title{
RUŚ KIJOWSKA MIĘDZY EURAZJĄ A EUROPĄ ŚRODKOWOWSCHODNIĄ. ROSYJSKIE NARRACJE TOŻSAMOŚCIOWE Z ZACHODNIEGO PUNKTU WIDZENIA
}

\author{
ARENT VAN NIEUKERKEN ${ }^{1}$ \\ (Uniwersytet Amsterdamski)
}

Słowa kluczowe: Ruś Kijowska, Rosja, Eurazja, Gumilow, Dugin

Keywords: Kievan Rus', Russia, Eurasia, Gumiliov, Dugin

\begin{abstract}
Abstrakt: Arent van Nieukerken, RUŚ KIJOWSKA MIĘDZY EURAZJĄ A EUROPĄ ŚRODKOWOWSCHODNIĄ. ROSYJSKIE NARRACJE TOŻSAMOŚCIOWE Z ZACHODNIEGO PUNKTU WIDZENIA, „PORÓWNANIA” 16 (2015), T. XVI. S. 19-30. ISSN 17330-165X. Po przyłączeniu Krymu przez Rosję Vladimira Putina nowego znaczenia nabrały próby ideologicznego uzasadnienia roli Wielkiej Rosji jako dominującej potęgi w Europie Wschodniej. Z tego punktu widzenia, jako istotne zagadnienie, jawi się relacja między Rusią Kijowską, tradycyjnie uważaną za kolebkę (słowiańskiej) rosyjskiej cywilizacji, a Wielkim Księstwem Moskiewskim, które zastąpiło Ruś Kijowską po inwazjach mongolskich. Rosyjskie narracje tożsamościowe zazwyczaj marginalizują obecny status Ukrainy i podkreślają jej peryferyjność w „świecie rosyjskim”. Aby to osiągnąć używają one zarówno teologicznych, kulturowych, jak i geopolitycznych argumentów, które czasami wydają się wzajemnie sprzeczne. Moskwa jest jednocześnie centrum prawdziwej (ortodoksyjnej) chrześcijańskiej wiary i cywilizacji w geopolitycznej przestrzeni Eurazji. W tym drugim przypadku rosyjska stolica sprawuje władzę nad multireligijnym imperium. (Neo)eurazjatyccy ideolodzy, tacy jak L.N. Gumiliov, a zwłaszcza Alexander Dugin odrzucają alternatywną, "zachodnią" wersję rosyjskiej (i ukraińskiej) historii, podkreślają bowiem, że istnieje nieprzekraczalna bariera między zachodnią a rosyjską (eurazjatycką) cywilizacją. Według nich zachodni naukowcy nigdy nie zrozumieją fenomenu historycznego rosyjskiego (eurazjatyckiego) rozwoju. Można dowodzić, że argument za relatywizacją zgodną z linią podziałów cywilizacyjnych zmniejsza uniwersalne oddziaływanie chrześcijaństwa, które w rosyjskim kontekście traci wiele ze swych transcendentnych sensów i zamiast tego staje się wyłącznie cechą kulturową. Chociaż
\end{abstract}

\footnotetext{
${ }^{1}$ Correpondence Address: A.J.vanNieukerken@uva.nl
} 
z drugiej strony, (nie do końca świadome) rozpatrywanie ortodoksyjnego chrześcijaństwa jako fenomenu kulturowego zwiększa moc argumentów geopolitycznych, zgodnie z którymi Moskwa jest centrum rosyjskiego świata (a sama Rosja centrum Eurazji). Jednakże, nie oznacza to, że kluczowa rola Moskwy, jako siedziby Patriarchatu dla wszystkich Rosjan, "prawomocnego" następcy dawnej metropolii kijowskiej, nie będzie wykorzystywana w zgodzie z tendencją, by podważać ukraińskie ambicje stworzenia całkowicie niezależnego państwa.

Abstract: Arent van Nieukerken, KIEVAN RUS' BETWEEN EURASIA AND EAST-CENTRAL EUROPE. RUSSIAN IDENTITY NARRATIVES FROM WEST VIEWPOINT, "PORÓWNANIA" 16 (2015), Vol. XVI. P. 19-30. ISSN 1733-165X. After the annexation of the Crimea by Vladimir Putin's Russia attempts at an ideological justification of Greater Russia's role as a dominating power in Eastern Europe have acquired a new relevance. An important issue from this point of view is the relationship between Kievan Rus' - traditionally considered the cradle of the [Russian civilization - and the Grand Principality of Moscow that replaced it after the Mongol incursions. Russian identity narratives usually marginalize the current status of (the) Ukraine and stress its peripherality in the "Russian world". In order to achieve this they employ both theological, cultural and geopolitical arguments that sometimes appear to be at odds with each other. Moscow is both the center of the true (orthodox) Christian faith and the civilization of the Eurasian geopolitical space. In the latter case the Russian capital rules a multi-religious empire. Eurasian ideologues like L.N. Gumiliov and particularly Alexander Dugin reject alternative, "Western" interpretation of Russian (and Ukrainian) history by pointing out that there exists an unbridgeable gap between the Western and the Russian (or Eurasian) civilization. According to them, Western scholars can never grasp the specificity of the Russian (Eurasian) historical development. It could be argued that this argument for a relativism along civilizational lines diminishes the universal impact of Christianity which (that) in the Russian context loses much of its transcendent sense and becomes - instead - a cultural feature. On the other hand, though, the (half-conscious) culturalization of orthodox Christianity gives more weight to geopolitical arguments in favor of Moscow as the center of the Russian World (and Russia as the center of Eurasia). However, this does not mean that the pivotal role of Moscow as the residence of the All Russian Patriarchate, the "legitimate" successor to the ancient metropolis of Kievan Rus', is not exploited, in order to discredit Ukraine's ambitions of becoming an independent state.

W dniu 21 maja 2014 rosyjski literaturoznawca i publicysta Andriej Diesnicki opublikował na portalu internetowym "Gazeta.ru” komentarz pt. Ruski świat po Stowiańsku (Руский мир после Славянска, <www.gazeta.ru>). Zaczyna od kilku pozornie luźno związanych obserwacji. Po pierwsze zwraca uwagę, że w uroczystościach z okazji przyłączenia Krymu do Federacji Rosyjskiej nie uczestniczył oficjalny przedstawiciel rosyjskiej cerkwi prawosławnej. Mogłoby się wprawdzie wydawać, że nie było takiej potrzeby, skoro współczesna Rosja jest państwem świeckim, jeśli nawet bierzemy pod uwagę, że prawosławie reprezentowane przez patriarchat mający siedzibę w Moskwie jest wyznaniem uprzywilejowanym. Następ- 
nie Diesnicki przytacza fragment z konstytucji samozwańczej Republiki Donieckiej. Prawosławie, „mające być wyznaniem przewodnim [первенствующеем] i panująсуm [господствующеем], jest $\mathrm{w}$ tym fragmencie wyraźnie utożsamione $\mathrm{z}$ patriarchatem moskiewskim. Może więc patriarchat moskiewski nie wysunął (na razie) postulatu bezpośredniego wcielenia trzech eparchii krymskich do struktury rosyjskiej cerkwi, ponieważ prawosławna metropolia kijowska (Diesnicki nie wspomina o autokefalicznej prawosławnej cerkwi ukraińskiej)2 siłą rzeczy jest podporządkowana patriarchatowi moskiewskiemu? Trzecia obserwacja Diesnickiego wydaje się zadawać kłam ścisłym powiązaniom między cerkwią a państwem rosyjskim. $\mathrm{W}$ niedawno opublikowanym projekcie o „podstawach [rosyjskiej] polityki kulturalnej” autorzy powołują się jedynie na „wspólne wszystkim religiom światowym normy i wartości”, a pomijają prawosławne korzenie państwa rosyjskiego. Tekst rosyjskiego publicysty i uczonego (Diesnicki specjalizuje się w studiach biblijnych) unaocznia jednak znaczenie problematyki religijnej dla tożsamości rosyjskiej i w ogóle narodów wschodniosłowiańskich. Okazuje się ponadto, że sprawy religijne mieszczą się prawie zawsze $\mathrm{w}$ szerszych horyzontach historiozoficznych wyznaczonych przez swoiście interpretowane procesy cywilizacyjne i narodotwórcze. W związku z tym chciałbym się zastanowić nad dwoma pytaniami: 1) w jaki sposób specyficzna rola religii prawosławnej w Rosji określa rosyjską (albo może raczej „ruską") tożsamość; 2) jakie jest znaczenie tej konstrukcji tożsamościowej dla interpretacji obecnego konfliktu ukraińsko-rosyjskiego, a zwłaszcza dla postaw rosyjskich?

U podstaw nowoczesnej tożsamości rosyjskiej (ruskiej) leży - zdaniem patriarchy rosyjskiej cerkwi prawosławnej Kiryła (właśnie na niego powołuje się Diesnicki) - koncepcja „ruskiego świata” (mira) albo inaczej „świętej Rusi”. Zdaniem obecnego patriarchy "całej Rusi” na ów "ruski świat składają się trzy kraje wschodniosłowiańskie, Mołdowa, Kazachstan i w ogóle wszystkie obszary, na których tradycyjnie żyją przedstawiciele kultury „ruskiej”: „Święta Ruś - to nie pojęcie etniczne ani polityczne czy językowe; jest to pojęcie duchowe... wspólnota wartości, wspólnota duchowego ukierunkowania". Właśnie w tym sensie wyłoniła się „ruska jedność duchowa, która jest wyższa ponad wszystkie granice polityczne". Ów ruski świat powstał kiedyś w okolicach Kijowa, lecz na przestrzeni dziejów jego ośrodek przemieścił się do Moskwy, gdzie pozostał do dziś dnia. Rdzeń "ruskiego" świata to prawosławna wiara, będąca kluczowym elementem ruskiej kultury zinstytucjonalizowanym przez cerkiew. W różnych epokach na jej czele

\footnotetext{
${ }^{2} \mathrm{O}$ implikacjach konfliktu między tymi zwalczającymi siebie wzajemnie reprezentantami prawosławia dyskutuje się jednak również w Rosji. W innym artykule opublikowanym na portalu internetowym "gazeta.ru" («Украинский мир» против «русского») autor (dziennikarz i reiligioznawca Borys Falikow) zwraca uwagę, że Ukraińska Cerkiew Patriarchatu Kijowskiego ma pozytywny stosunek do „pluralizmu demokratycznego pokroju europejskiego w ramach państwa narodowego, sprowadzając tzw. ruski świat do archaiki imperialnej".
} 
stali - streszczam tu rozważania Diesnickiego - metropolici kijowscy i moskiewscy, a obecnie patriarcha moskiewski, którego kierownicza rola jest prawowitą kontynuacją kijowskich początków. Rzuca się natychmiast w oczy, że taka konstrukcja znaczenia prawosławia dla "ruskiej” tożsamości skazuje przestrzeń wokół Kijowa, czyli obecną Ukrainę, z góry na drugorzędność. Taka narracja niesie też ze sobą inne niebezpieczeństwo, a mianowicie to, że charyzma patriarchatu moskiewskiego zostanie samorzutnie przeniesiona na strukturę państwową mającą swoją siedzibę w Moskwie. Ustrój tego państwa (samodzierżawie, autokracja), przedstawiany często jako logiczny wynik procesów dziejowych po upadku Rusi Kijowskiej (chodzi o tzw. zbieranie "ruskich” ziem przez wielkich książąt moskiewskich), jest wtedy dodatkowo legitymizowany przez sakralny autorytet głowy cerkwi. Typowa pod tym względem wydaje się opinia współczesnego ideologa rosyjskiego Aleksandra Dugina (w drugiej części tego tekstu będę rozważał rodowód jego poglądów na specyfikę Rosji i ruskiego świata), który podkreśla, że „w epoce Rusi kijowskiej obszar obecnej Ukrainy był centrum państwowym Słowian wschodnich, dla których Władymir (później Moskwa) był wschodnim krańcem, a Nowogród [Wielki] krańcem północnym” (Dugin 377). Później zaś, „w miarę stopniowego przekształcania się Rusi z państwa słowiańskiego w imperium eurazjatyckie”, stosunek ten odwrócił się, o czym świadczy nazewnictwo: „historyczny sens Ukrainy odzwierciedla się w jej nazwie - »Ukraina«, tzn. kraniec [okraina], czyli terytoria pograniczne" (Dugin 377). Dlatego Ukraina nie ma - zdaniem Dugina - żadnego samodzielnego znaczenia geopolitycznego. Posiada wprawdzie własny język i kulturę, lecz one są pozbawione wszelkiego znaczenia "uniwersalnego" (Dugin 379).

Następnie Diesnicki, który reprezentuje oczywiście zupełnie inny sposób myślenia niż eurazjata Dugin, rozważa znaczenie Rusi Kijowskiej w świetle alternatywnej narracji tożsamościowej: „inna mitologia polityczna uważa, że kijowska linia rozwoju Rusi znalazła kontynuację w Wielkim Księstwie Litewskim, które było - pierwotnie - również prawosławnym państwem, tyle, że wolnym". Mniejsza tu o zgodność jego reprezentacji państwa litewskiego z historyczną prawdą. Ważne jest tu coś innego. Widzieliśmy, że rosyjski publicysta stawia, właściwie bez podania motywacji - jakby chodziło o coś oczywistego - znak równości między duchową tradycją „ruskiego świata” a pewnymi ustrojami politycznymi, przeciwstawiając samodzierżawie strukturze mniej scentralizowanej i pozwalającej na większą swobodę indywidualną (zresztą również w państwie moskiewskim jednostka może jego zdaniem być wolna, tyle, że jako wyznawca wiary chrześcijańskiej, ale nie jako obywatel państwa). Problem z tą drugą linią rozwojową biorącą początek na Rusi Kijowskiej polega jednak na tym, że podobnie jak republika Nowogród (Wielki), ów - zdaniem wielu - ostatni relikt starej Rusi, Wielkie Księstwo Litewskie stosunkowo szybko zakończyło swoje życie. Przytoczyć można tu znów opinię Dugina, który uważa, że po upadku Rusi Kijowskiej jej dawna stolica 
stała się zaledwie „drugorzędnym ośrodkiem, w którym spotykały się wpływy euroazjatyckie z środkowoeuropejskimi" (Dugin 377). Ideolog putinowskiej Rosji uważa, że w odróżnieniu od Wielkiego Księstwa Moskiewskiego - czyli dawnego krańca Rusi Kijowskiej - ów nowy organizm ukraińsko-litewski nie mógł aspirować do statusu podmiotu kulturotwórczego. Nie potrafił stworzyć bowiem „syntezy" kultur. Państwo to, na które składały się przede wszystkim tereny słowiańskie, a mianowicie późniejsza Ukraina i Białoruś, uległo więc "dynamicznemu, bardziej 'modernistycznemu' oddziaływaniu Europy Zachodniej - w szczególności Polsce na zachodzie i Imperium austro-węgierskiemu na zachodnim południu" (Dugin 379) ${ }^{3}$. Później Ukrainę podzielili między siebie przedstawiciele cywilizacji Europy Zachodniej (Polacy, później Austriacy) i Rosjanie, reprezentujące cywilizację eurazjatycką.

Co z punktu widzenia Dugina i innych zwolenników koncepcji eurazjatyckiej wygląda na logiczny wynik szerszych procesów cywilizacyjnych przeobrażających swoistą ziemię niczyją, przedstawiło się oczywiście zupełnie inaczej zwolennikom idei przypisującej Ukrainie, a tym samym stanowiącej jej kolebkę kulturze Rusi Kijowskiej, pewną samodzielność i trwałość (w tym przypadku chwilowe [?] niepowodzenia historyczne tej kultury nie obniżają jej wartości). Wyznacznikiem tej trwałości były "starodawne swobody”, które z punktu widzenia zwolenników mitu "litewskiego" łączą Wielkie Księstwo Litewskie właśnie z Rusią Kijowską, przy czym brak rządów centralnych w starej Rusi niektórzy historycy wykorzystywali jako argument zbliżający spadkobierców Rusi Kijowskiej, tzn. Wielkie Księstwo Litewskie i późniejsze państwo hetmańskie Chmielnickiego (ale także Nowogród Wielki sprzed wcielenia do Wielkiego Księstwa Moskiewskiego), do „Europy” (Kohut 565-568, Plokhy 171-172, Pelenski) ${ }^{4}$. Z takiego punktu widzenia

${ }^{3}$ W innym kontekście Dugin przytacza opinię pewnych historyków - w szczególności Oswalda Spenglera - którzy „mówili o istnieniu osobnej »cywilizacji bałtyckiej«”, której obszar pokrył się z granicami historycznymi Polski i Litwy (czyli - według Dugina - „Księstwa polsko-litewskiego”). Cywilizacja ta upadła jednak, zanim osiągnął swój najdojrzalszy kształt i okazała się "aborcyjna” (Dugin 373). Dugin uważa, że samodzielne istnienie geopolityczne polsko-litewskiej przestrzeni stanowi istotną przeszkodę dla mającej się wyłonić proeurazjatycki byt bałtycki, którego ośrodkiem będą - na razie nieistniejące - Prusy. Trzeba więc doprowadzić do integracji fragmentów tej cywilizacji (jednym z jej wyznaczników jest katolicyzm) w innych blokach geopolitycznych. Polska - w oderwaniu od Litwy - mogłaby wtedy wejść do właśnie katolickiego bloku południo-środkowo-europejskiego, którego miejsce kiedyś zajmowała monarchia habsburska (Dugin 373). Litwa zaś, państwo nie mniej katolickie niż Polska, powinna ze względu na swoje położenie geograficzne (oddziela przestrzeń eurazjatycką od Bałtyku) wejść do przyjaźnie wobec Eurazji/Rosji nastawionej przestrzeni północnej (Prusy!).

${ }^{4}$ Z takiego punktu widzenia - łączącego działającego w Kijowie historyka Michaiła Kostomarova z Galicjaninem Michajłem Hruszewskim, Rzeczpospolita Obojga Narodów bynajmniej nie była braterską unią dwóch narodów, lecz rezultatem podboju, wprawdzie administracyjnego i cywilizacyjnego, słabszego partnera - Litwy - przez silniejszego - Polskę. Moskali zaś przedstawiano w tym schemacie 
wzorce polityczne przypominające zachodnie społeczeństwo „obywatelskie” okazują się więc wyznacznikiem odwiecznej „Europejskości” Ukrainy. Nie zostały one bowiem - wbrew temu, co sugeruje Dugin - importowane z "Zachodu" po upadku Rusi Kijowskiej.

Zdaniem Diesnickiego nie ma sensu zastanawiać się nad prawdziwością tych mitów. Nie odzwierciedlają one bowiem rzeczywistości historycznej, lecz są ideologicznymi konstruktami ${ }^{5}$. W prezentacji tych dwóch narracji założycielskich chodzi mu o ich znaczenie dla chwili bieżącej. Rzecz bowiem w tym, że jeszcze niedawno spory związane $\mathrm{z}$ tymi mitami miały spokojny i czysto intelektualny charakter, podczas gdy od marca 2014 (czyli od chwili aneksji Krymu i rosyjskiej interwencji na wschodniej Ukrainie) koncepcja „ruskiego świata” stała się kluczowym pojęciem rosyjskiej polityki zewnętrznej (albo - z punktu widzenia Rosjan raczej zewnętrzno-wewnętrznej). Diesnicki zdaje sobie zresztą sprawę, że rosyjska propaganda wykorzystuje prawosławną narrację tożsamościową w dosyć jednostronny sposób. Władimir Putin często motywuje roszczenia Rosji do Krymu tym, że pierwszego chrześcijańskiego władcę Rusi Kijowskiej, Świętego Włodzimierza, ochrzczono właśnie na tej półwyspie, w bizantyjskim mieście Chersonie (Korsuń), w pobliżu obecnego Sewastopola (np. w przemówieniu do zgromadzenia federalnego w dniu 4 grudnia 2014, w którym rosyjski przywódca porównał znaczenie Krymu z sakralnym statusem Góry Świątynnej w Jerozolimie dla wyznawców Islamu i Judaizmu) ${ }^{6}$. Skądinąd jednak wiadomo, że właśnie w Chersonie apostołowie Słowian Cyryl i Metody w sto lat wcześniej znaleźli relikwie rzymskiego papieża św. Klemensa, zesłanego na Krym za panowania cesarza Trajana (według innej wersji legendy apostołowie Słowian wydobyli zwłoki świętego z morza i następnie zanieśli do głównego kościoła miasta). Kolebka tożsamości prawosławnej, mającej stanowić o samodzielności cywilizacji „ruskiej” w stosunku do

jako poddanych słowianizacji potomków Ugrofinów, którzy - ze względu na odmienność „plemienną" - nie czuli się w żaden sposób związani z kijowską starożytnością (podobny pogląd można znaleźć u Mickiewicza w Prelekcjach paryskich).

${ }^{5}$ Podobną uwagę można znaleźć w recenzji pióra D.B. Millera (2000) z książki Jarosława Pelenskiego (por. Dugin 377) The Contest for the Legacy of Kievan Rus': „Pelenski writes about the emergence in the nineteenth century of a Ukrainian historiography, crowned by Hrushevsky's History, challenging the claims of the Russian national school to a monopoly on the Kievan heritage. For the most part his argument is exemplary, but might not the continuity the author claims between periodic assertions of a Ukrainian history from the sixteenth century on and his nineteenth-century revisionists better be interpreted as a construction of the latter group in making the case for an uninterrupted Ukrainian historical consciousness. In the essay Pelenski proposes Tatar precedents for Muscovite institutions and values, among them the slavish manner in which Russian aristocrats allegedly addressed their tsars. The subtext is that Muscovy in important respects exhibited discontinuities from Rus' tradition". Zobaczymy jeszcze, że argument Pelenskiego jest tylko lustrzanym - tyle, że negatywnie wartościowanym - odbiciem tez wysuniętych przez eurazjatów takich jak L. N. Gumilow i Dugin.

${ }^{6}$ Zob. (Новая Газета 2014). 
Zachodu (tzn. do łacińsko-germańskiej Europy), miała zatem łączność z początkami (czy może raczej prehistorią) odrzuconej przez późniejszych Rosjan cywilizacji „europejskiej"7.

Diesnicki nie rozwija tego paradoksu. Uważa jednak, że tego typu fakty historyczne $\mathrm{w}$ wielce pożyteczny sposób komplikują narodowe lub kulturowe narracje założycielskie. Utrudniają bowiem wykorzystywanie prawd religijnych w celach ideologicznych i uwydatniają znaczenie przesłania Chrystusowego dla człowieka jako osoby, jednostki: „Cerkiew nie powinna obecnie mówić o ruskim lub jakimkolwiek innym świecie, lecz o Chrystusie i Ewangelii. Takie właśnie jest jej prawdziwe zadanie". Trzeba jednak powiedzieć, że właśnie w Rosji było - i jest - wiele prób, by elementy religijne traktować jako reprezentacje mechanizmów cywilizacyjnotwórczych. Zresztą chrześcijańska idea wolności osoby zakorzenionej w istotowej relacji między człowiekiem a Bogiem-człowiekiem, Chrystusem, stała się w zsekularyzowanej formie podstawą społeczeństw łacińsko-germańskich, innymi słowy: wyznacznikiem cywilizacyjnym, tyle, że w „Europie” owa religijnie umotywowana idea wolności osoby, nie przestając być produktem i wyznacznikiem określonej cywilizacji, aspiruje $\mathrm{w}$ zasadzie do uniwersalności. Wróćmy jednak do przestrzeni wschodniosłowiańskiej. Obecne próby oceny znaczenia prawosławia dla cywilizacji „ruskiej” mają często dosyć specyficzny charakter. Czysto wyznaniowe aspekty cywilizacji staroruskiej podporządkowują się narracji szerszej, wykraczającej poza kontekst religijny, która okazuje się jednak zakorzeniona w sacrum. Cywilizacyjny (kulturowy) relatywizm idzie tu w parze $\mathrm{z}$ mesjanistyczną perspektywą przeciwstawiającą cywilizację ruską (sto lat temu powiedzielibyśmy za Bierdiajewem „ideę ruską") innym typom cywilizacyjnym, a zwłaszcza cywilizacji zachodniej, „europejskiej”. Trzeba przy tym zaznaczyć, że relatywistyczna epistemologia charakteryzująca tę świadomie mityczną (mitotwórczą) odmianę nauki o kulturach i cywilizacjach okazuje się - przynajmniej z rosyjskiego punktu widzenia - bardzo skuteczną bronią w dyskusji z uczonymi pochodzącymi $z$ innych kręgów kulturowych, którzy próbują na podstawie tych samych faktów konstruować alternatywne narracje tożsamościowe. Jeden z najbardziej wpływowych reprezentantów neoeurazjanizmu w Rosji, wspomniany już Aleksander Dugin, łączy explicite mesjańską misję Rosji z całkowicie relatywistyczną, a więc w pewnym sensie postmodernistyczną epistemologią. Historia Rosji (ruskiego świata) jest bowiem produktem światopoglądu, który ze swojej strony okazuje się wyrazem pewnej cywilizacyjnej determinacji i z takiej właśnie perspektywy należy oceniać „ruski” „mesjanizm” i „uniwersalizm”. Właśnie dlatego nasi sąsiedzi

\footnotetext{
${ }^{7}$ Epizod ten można znaleźć w wszystkich klasycznych dziełach rosyjskiej historiografii (Karamzin, Sergiej Sołowiow etc.). Po chrzcie i ślubie z bizantyjską księżniczką Anną, Włodzimierz przywrócił zdobyte miasto Grekom, wywożąc naczynia kościelne, ikony i relikwie św. Klemensa i jego ucznia Teby. $W$ relacjach rosyjskich nie wspomina się o tym, że Klemens był papieżem.
} 
a zwłaszcza ci z Zachodu, którzy mają własną i zupełnie odmienną od „ruskiej” odmianę mesjanizmu i uniwersalizmu, wypracowali dosyć krytyczną koncepcję „ruskiej historii” (odmienność ta polega chyba na tym, że Zachód - „Europa” - nie uznaje absolutnego charakteru różnic kulturowych i cywilizacyjnych, ponieważ taki pogląd jest sprzeczny $\mathrm{z}$ istotowym podobieństwem wszystkich ludzi jako wolnych "osób"; zachodni uczeni dochodzą więc do wniosku, że dzieje Rosji są smutnym przykładem tego, jak "ruski” człowiek odmawia - przynajmniej na poziomie społeczeństwa i państwa - „bycia osobą" i dlatego mija się ze swoją podstawową, ludzką godnością). Dugin, który chyba z uwagą śledzi rozwój metodologiczny nauki "zachodniej”, wyciąga z tego stanu rzeczy mało zaskakujący wniosek. Nurty dominujące $w$ dotychczasowej historiografii rosyjskiej stanowiły i wciąż stanowią - w mniejszym lub większym stopniu przejawy skłonności do autokolonizacji (opisując to zjawisko, Dugin nie używa wprawdzie tego terminu, ale nie ulega moim zdaniem wątpliwości, że świadomie nawiązuje do popularnej obecnie na Zachodzie krytyki postkolonialnej). Dotyczy to zarówno „liberalnych”, jak i „konserwatywnych” konstrukcji dziejów Rosji. Właściwie tylko słowianofile i kontynuujący ich podejście do historii Rosji eurazjaniści nie padli - zdaniem Dugina - ofiarą tej tendencji. Nie dziwi przy tym, że takie narracje zupełnie inaczej interpretują status i znaczenie Rusi Kijowskiej niż nauka "zachodnia”, „polska”, a może także „ukraińska”.

Nasuwa się tu dosyć oczywista wątpliwość. Na podstawie jakich kryteriów możemy stwierdzić, że jedna cywilizacja jest nieprzenikalna dla drugiej? Nie może tu przecież być żadnej perspektywy nadrzędnej, pozwalającej nam objąć jednym nieuprzedzonym spojrzeniem wszystkie istniejące byty cywilizacyjne i określić ich specyfikę, jako że nasze spojrzenie jest - w świetle teorii o cywilizacyjnej determinacji jednostki - z góry nacechowane kulturą lub cywilizacją, do których należymy. Paradoks ten nie daje się rozwiązać, dopóki nie zrezygnujemy z absolutyzacji rozumu, który okazuje się właśnie "partykularnym” elementem zachodniej, łacińsko-germańskiej narracji kulturowej. Pięta achillesowa „zachodnich” narracji wywodzących uprzywilejowany status kultury europejskiej z uniwersalnych właściwości oświeceniowego rozumu została bardzo wcześnie zauważona przez rzeczników rzekomej [?] samodzielności cywilizacji „ruskiej”. Sprawa ta wraca w najrozmaitszych kontekstach. Przeciwnicy „Europy” nie boją się przy tym zarzutu irracjonalności. Autor wpływowej syntezy o rozwoju cywilizacji „ruskiej” Od Rusi do Rosji, syn rozstrzelanego przez bolszewików poety Nikołaja Gumilowa i Anny Achmatowej, Lew Nikołajewicz Gumilow - za chwilę będę się szerzej zastanawiał nad jego koncepcjami cywilizacyjnymi - w wypowiedziach publicystycznych przyznawał się bez oporów do irracjonalistycznych korzeni swoich poglądów ${ }^{8}$.

8 „Rosja jest samodzielnym superetnosem, który powstał 500 lat po zachodnioeuropejskim, w XIV wieku. My i zachodnioeuropejczycy zawsze wyczuwaliśmy tę różnicę i nigdy nie uważaliśmy siebie 
W ostatniej części tego tekstu chciałbym pokazać, w jaki sposób z perspektywy ideologii eurazjatyckiej narracje założycielskie, traktujące Ruś Kijowską jako początek historii „ruskiej”, ulegają ponownej interpretacji. Celem takich reinterpretacji dokonywanych za pośrednictwem rekontektualizacji geograficznej ziem rosyjskich jest obalenie konstrukcji historycznych i cywilizacyjnych wywodzących istotę „świata rosyjskiego" i „Europy” (świata "łacińsko-germańskiego") z tego samego źródła. Problem wynika - jak już widzieliśmy - przede wszystkim z przynależności zarówno „Europy”, jak i świata ruskiego do obszaru chrześcijaństwa. Trzeba więc odebrać chrześcijaństwu jego decydujące znaczenie dla niepowtarzalnego piętna danej kultury, a zarazem zachować jego nadprzyrodzony autorytet. Specyficznie "ruska” forma chrześcijaństwa okazuje się świadomym zjawiskiem kulturowym, lecz ta okoliczność w niczym nie zmniejsza absolutnego wyzwania, który przesłanie Chrystusowe rzuca człowiekowi. Ów człowiek nie jest jednak człowiekiem, jako takim, z perspektywy uniwersalistycznej antropologii (widzieliśmy przecież, że ta antropologia jest produktem partykularnej cywilizacji europejskiej), nie jest „osobą”, lecz człowiekiem „ruskim”. Eurazjaniści próbowali przezwyciężyć ten paradoks poprzez wypracowanie nowej mitologii tożsamościowej opierającej się na odmiennej interpretacji procesów cywilizacyjnotwórczych. Można np. wysunąć hipotezę, że nie ma prostej ciągłości między chrześcijaństwem późnej starożytności (imperium bizantyjskie stanowiłoby jego przedłużenie) a najgłębszymi elementami tożsamościowymi nowych cywilizacji, które we wczesnym średniowieczu wyłaniały się stopniowo w Europie Zachodniej i Wschodniej. Istotowa różnica między tymi cywilizacjami byłaby wtedy nie tyle skutkiem Wielkiej Schizmy między kościołami wschodnim i zachodnim, lecz przyczyna wyboru różnych dróg religijnych narzuconych przez odmienne predyspozycje kulturowe. Rzecz jednak w tym, że w takim przypadku Ruś Kijowska nie może być początkiem odrębnej tożsamości „ruskiej”. Różnica w stosunku do „Europy”, a zwłaszcza do tych słowiańskich narodów, które wchodziły w X i XI wieku do cywilizacji "zachodniej", wydaje się na etapie Rusi Kijowskiej niedostatecznie wyrazista.

Mogłoby się więc wydawać, że Ruś Kijowska była w istocie bytem cywilizacyjnie słabo określonym, w odróżnieniu od późniejszej „Świętej Rusi”, nie mogącym aspirować do samodzielności wobec cywilizacji europejskiej („romańskogermańskiej, jak mówi Gumilow). Taką drugorzędną rolę w genezie cywilizacji

na wzajem 'swoich'. Jako że jesteśmy o 500 lat młodsi, nie możemy teraz osiągnąć dobrobytu i obyczajowości typowej dla Europy. Nasz wiek, nasz poziom "pasjonarności«, zakłada zupełnie inne imperatywy postępowania. Można oczywiście próbować »wejść w krąg cywilizowanych narodów«, tzn. innego superetnosu. Ale nie ma nic za darmo. Trzeba zdawać sobie sprawę, że takie przyłączenie się będzie zawsze równoznaczne $\mathrm{z}$ odrzuceniem rodzimych tradycji, a następnie $\mathrm{z}$ asymilacją". (L. N. Gumilow w wywiadzie dla Leningradzkiej Prawdy [1990]). 
„ruskiej” przeznaczyli Rusi kijowskiej twórcy ideologii euroazjatyckiej ze słynnym językoznawcą Mikołajem Trubieckim na czele. Okazuje się, że rodowodu „Świętej Rusi" należy poszukiwać gdzie indziej. Doświadczenia historyczne istotne dla formacji „ruskiego świata” (jawi się on jako o kilkaset lat młodszy - więc bardziej witalny, "pasjonarny” - rywal szybko starzejącej się cywilizacji „europejskiej”) dokonały się bowiem dopiero po podboju i częściowym unicestwieniu księstw Rusi kijowskiej przez Mongołów. Ośrodek tego procesu cywilizacyjnotwórczego stanowiło Wielkie Księstwo Moskiewskie, a jego ideologia łączyła prawosławną spuściznę religijną z nową koncepcją państwowości, która była bezpośrednią reakcją na porażkę Rusi Kijowskiej w starciu z potomkami Dżingis-Chana. Święta Ruś została w pewnym sensie inkorporowana do mongolskiej cywilizacji stepowej, tyle, że po dwustu latach stała się dominującą siłą tego eurazjatyckiego bytu cywilizacyjnego, przejmując jednak wiele mongolskich cech, takich jak (streszczam Dugina): „dynamiczność i okrucieństwo mongolskich wojsk, skuteczność systemu pocztowych koni (,jamskoj sv'azi"), racjonalność ściągania trybutu, obyczaj szorstkiego centralizmu administracyjnego, surowej hierarchii”. Tożsamość „ruskiego" świata określają w związku z tym następujące cechy ogólne (cytuję znów Dugina): „ustrój tradycyjny, żołnierska etyka, religijna samoistność, świadomość znaczenia jedności i dyscypliny, podporządkowania się i organizacji centralizowanej, która uwidoczniała się u Mongołów i uchodziła za mocną stronę w sensie historyczno-politycznym (jej zlekceważenie stało się przyczyną rosyjskiej porażki w XIII wieku)". Wydaje się więc, że z punktu widzenia Dugina siła prawosławia polega przede wszystkim na jego przywiązanu do tradycji. Tradycja ta jest wprawdzie chrześcijańska, lecz taka koncepcja cywilizacyjna pozostawia też miejsce dla innych wyznań i religii pod warunkiem, by przestrzegały przesłania swoich początków. Mielibyśmy tu do czynienia z tradycjonalistycznym wariantem idei ekumenicznej (należy więc, podobnie jak w stepowym imperium mongolskim, respektować wszystkie wyznania i religie, ponieważ posiadają „wspólne normy i wartości"). Tradycjonalizm starowierców, chociaż skończył się sekciarstwem, wydaje się z takiego punktu widzenia jak najbardziej do pogodzenia z ideą cywilizacyjną „Świętej Rusi”. Protestanckie sekty zachodnie zasługują jednak na jednoznaczne potępienie, bo stawiają na nowinki i podważają „wspólne normy i wartości"; trzeba więc czynnie przeciwdziałać ich próbom opanowania „ruskich” ziem.

Ruś Kijowska, której przede wszystkim brakowało jedności i dyscypliny, ponieważ nikt tu nie chciał się nikomu dobrowolnie podporządkować, jawiła się eurazjanistom $\mathrm{w}$ dwóch aspektach: jako byt kulturowo niedorozwinięty, albo według koncepcji spadkobiercy klasycznego eurazjanizmu, wspomnianego już Lwa Nikołajewicza Gumilowa - jako późna, schyłkowa faza wcześniej już istniejącej cywilizacji „słowiańskiej”. Końcowym etapem tej cywilizacji jest rozpad jedności, najpierw ogólnosłowiańskiej, następnie „ruskiej”. Z drugiej jednak strony roz- 
kwit kultury materialnej i duchowej przypada często na późniejsze etapy rozwoju cywilizacyjnego (Gumilow używa terminu „etnogenezy”). Okoliczności tej zawdzięczamy wspaniałą kulturę Rusi kijowskiej. Łatwiej teraz - mimo tego pozytywnego elementu rozkwitu kultury upadającej cywilizacji słowiańskiej - zrozumieć, dlaczego eurazjaniści, chociaż na ogół pozytywnie oceniali myślenie rosyjskich słowianofilów, stanowiące ich zdaniem jedyną sensowną alternatywną narrację tożsamościową wobec ulegających Zachodowi liberalnych i konserwatywnych nurtów „etatystycznych”, niekoniecznie wypowiadali się za ideą panslawistyczną.

Jak $\mathrm{w}$ takim razie należy wytłumaczyć fakt, że w ideologicznie mniej wyrazistych konstrukcjach dziejów „ruskiego” świata Ruś Kijowska jest przedstawiana nie tylko jako kolebka tej cywilizacji, lecz wręcz jako swoisty złoty wiek? Wydaje się, że w tym przypadku inny model historiozoficzny, w swej istocie cykliczny, nakłada się na linearny model rozwojowy. Gumilow uważał, że taki wizerunek Rusi Kijowskiej pojawił się z perspektywy upadającej Rusi bezpośrednio przed najazdem Mongołów. Później narracje tę podejmowali i kontynuowali, mechanicznie ją powielając, kronikarze Wielkiego Księstwa Moskiewskiego. Idea złotego wieku jawi się tu jako typowy przykład narracji założycielskiej wspominającej z melancholią utraconą jedność. Byłaby więc historyczną rekontekstualizacją mitu o wygnaniu z raju. Skądinąd taka koncepcja świadczy o sile nowego bytu cywilizacyjnego, "Świętej Rusi”. Stworzyła ona mitologię wcielającą do jej tradycji byty kulturowe, które są jej właściwie obce z perspektywy własnej dynamiki historycznej. Takie mity drugiego stopnia mogą oczywiście łatwo dostarczać i właściwie zawsze dostarczały - pretekstów, by usprawiedliwiać rosyjską politykę imperialną.

Wbrew narracji o złotym wieku rzuca się jednak w oczy, że w obu konstrukcjach dziejów (historyczne limbo przed powstaniem Świętej Rusi albo dojrzały etap cywilizacji poprzedzającej „ruski świat”) Ruś Kijowska, której terytorium pokrywało się w znacznym stopniu z obecną Ukrainą, nie może być równoprawnym partnerem Moskwy na poziomie „ruskiego świata”. Bo to przecież nie ona nadała tej cywilizacji (Gumilow wymyślił dla takich nadrzędnych jednostek kulturowo-etnicznych termin "superetnos") jej istotę. W najlepszym przypadku może ona aspirować - znów używam terminologii Gumilowa - do statusu etnosu w ramach rosyjskiego („ruskiego") superetnosu, którego ideologiczne - „duchowe" - centrum stanowi Moskwa. Cywilizacja (etnos? superetnos?), której dosyć późnym etapem była Ruś Kijowska, przestała bowiem istnieć. Jej ostatnim reprezentantem było republikańskie miasto Nowogród Wielki, które jednak zostało zaanektowane przez wielkiego księcia moskiewskiego Iwana III i w sto lat później unicestwione przez pierwszego cara Iwana IV Groźnego. Można żałować, że tak się stało, ale dzieje etnosów i superetnosów nie kierują się względami sentymentalnymi. Cywilizacja, której relikt stanowił Nowogród Wielki, straciła wszelką 
żywotność, więc upadek tej republiki słowiańskich kupców był uzasadniony. Wydaje się, że przewaga i sukces polityczny są tu wyrazem pewnej wyższej sprawiedliwości dziejowej, co świadczyłoby o tym, że mesjanizm i uniwersalizm „Świętej Rusi" wykracza - wbrew założeniom epistemologicznym myślicieli takich jak Gumilow i Dugin - granice cywilizacyjnego relatywizmu. Jak „ruscy ludzie” intuicyjnie czujemy, że Nowogród Wielki nie ma prawa do politycznego samostanowienia, bo jego obszar jest cywilizacyjnie niczyj. Opanuje go albo "Zachód”, albo "Święta Ruś. Konsekwencje takiej interpretacji dziejów „ruskich” dla obecnej Ukrainy są jasne. Nie ma właściwie żadnej cywilizacyjnej relacji między Ukrainą a istniejącą kiedyś na jej terytorium Rusią Kijowską. Ukraińcy są bowiem dosyć peryferyjnym etnosem $\mathrm{w}$ ramach superetnosu, któremu na imię "Święta Ruś". Skoro jednak Ukraińcy nie zawsze uświadamiają sobie swoją „prawdziwą” przynależność cywilizacyjną, trzeba ich do niej przekonać. Należy w tym celu zwalczać dwa błędne poglądy. Pierwszy zakłada, że Ukraina dlatego, iż stanowiła kiedyś część Wielkiego Księstwa Litewskiego, należy do - i tak dobiegającej swojego kresu, bo o kilkuset lat starszej od „ruskiej” - cywilizacji zachodniej („romańsko-germańskiej"). Drugi pogląd zakłada istnienie rdzennie-ukraińskiego modelu cywilizacyjnego, którego istota wywodziłaby się z mitu kozackiego. Kozacy poddali się jednak Świętej Rusi w Perejasławiu w roku 1654. To, co Chmielnicki prawdopodobnie uważał za tymczasowe przymierze, by odeprzeć najazd polski, było z punktu widzenia cara Aleksego i jego doradców realizacją sprawiedliwości historyczno-cywilizacyjnej, chociaż brakowało im ideologicznego aparatu pojęciowego, by uzasadnić to doniosłe zdarzenie historyczne.

\section{BIBLIOGRAFIA}

[Dugin] Дугин, Александр. Основы геополитики. Moskva: АРТОГЕЯ-центр, 2000.

Kohut, Zenon E. "The Development of a Little Russian Identity and Ukrainian Nationbuilding". Harvard Ukrainian Studies 3/4 (1986).

Miller, David B. "The Contest for the Legacy of Kievan Rus'". The Journal of Modern History 2 (2000).

Новая Газета, Web. 07. 12.2014. <http:/ / www.novayagazeta.ru/news/1689924.html>

Plokhy Serhii. Unmaking Imperial Russia: Mykhailo Hrusheosky and the Writing of Ukrainian History. Toronto: University of Toronto Press, 2005.

Pelenski Jaroslav. The Contest for the Legacy of Kievan Rus'. New York 1998.

Web. 12.08.2014. <http://www.gazeta.ru/comments/column/desnitsky/6039473.shtml>

Web. 12.08.2014. <http://www.gazeta.ru/comments/2014/04/16_a_5994773.shtml> 